\title{
Ceramicrete Stabilization of CST Resin: ITP Alternative Phase III Feasibility Study
}

by

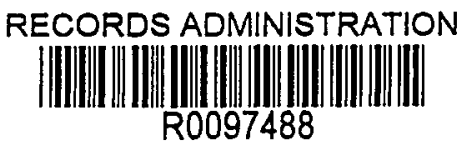

C. A. Langton

Westinghouse Savannah River Company

Savannah River Site

Aiken, South Carolina 29808

DOE Contract No. DE-AC09-96SR18500

This paper was prepared in connection with work done under the above contract number with the U.S.

Department of Energy. By acceptance of this paper, the publisher and/or recipient acknowledges the U.S. Government's right to retain a nonexclusive, royalty-free license in and to any copyright covering this paper, along with the right to reproduce and to authorize others to reproduce all or part of the copyrighted paper. 


\section{DISCLAIMER}

This report was prepared as an account of work sponsored by an agency of the United States Government. Neither the United States Government nor any agency thereof, nor any of their employees, makes any warranty, express or implied, or assumes any legal liability or responsibility for the accuracy, completeness, or usefulness of any information, apparatus, product, or process disclosed, or represents that its use would not infringe privately owned rights. Reference herein to any specific commercial product, process, or service by trade name, trademark, manufacturer, or otherwise does not necessarily constitute or imply its endorsement, recommendation, or favoring by the United States Government or any agency thereof. The views and opinions of authors expressed herein do not necessarily state or reflect those of the United States Government or any agency thereof.

This report has been reproduced directly from the best available copy.

Available to DOE and DOE contractors from the Office of Scientific and Technical Information, P. O. Box 62, Oak Ridge, TN 37831; prices available from (423) 576-8401.

Available to the public from the National Technical Information Service, U. S. Department of Commerce, 5285. Port Royal Road, Springfield, VA 22161. 


\section{DISCLAIMER}

Portions of this document may be illegible in electronic image products. Images are produced from the best available original document. 
WSRC-TR-00338

$\because$

REV. 0

KEY WORDS: Ceramic Waste Form

Cesium

Salt Waste Treatment

RETENTION: Permanent

CERAMICRETE STABILIZATION OF CST RESIN:

SALT WASTE ALTERNATIVE PHASE WI FEASIBIITY STUDY (O)

\author{
Author \\ Christine A. Langton, \\ Westinghouse Savannah River Company \\ Savannah River Technology Center, \\ Aiken, SC 29808
}

Date: September 30, 1998

Westinghouse Savannah River Company

Savannah River Site

Aiken, SC 29808

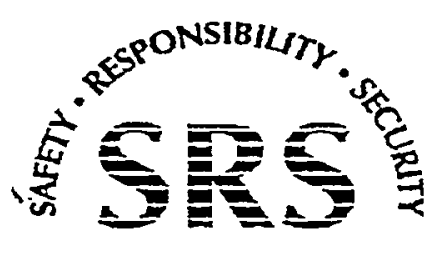


WSRC-TR-98-00338

Revision: 0

September 30, 1998

\section{REVIEWS and APPROVALS}

\section{Author}

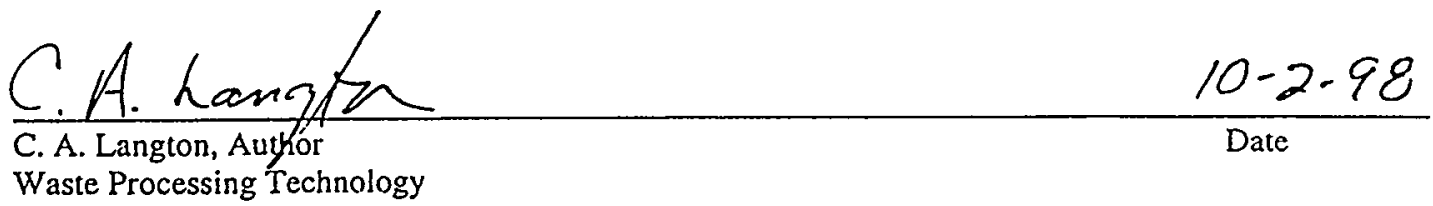

\section{Approvals/Review}

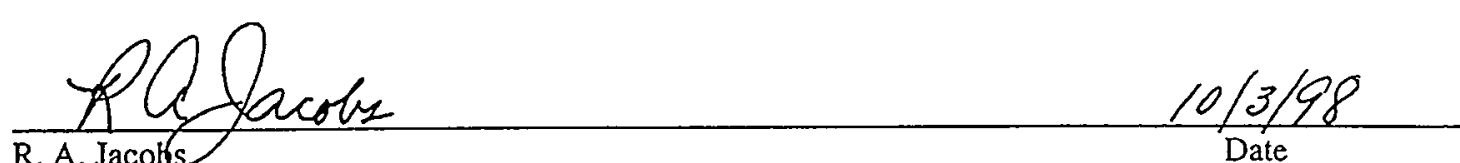

R. A. Jacobs
Salt Disposition Flowsheet Team

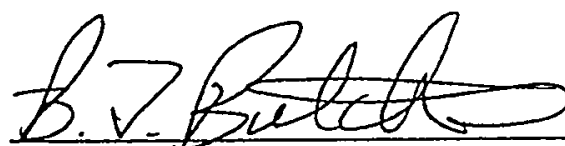

B. T. Butcher, Level 4

Date

Waste Processing Technology

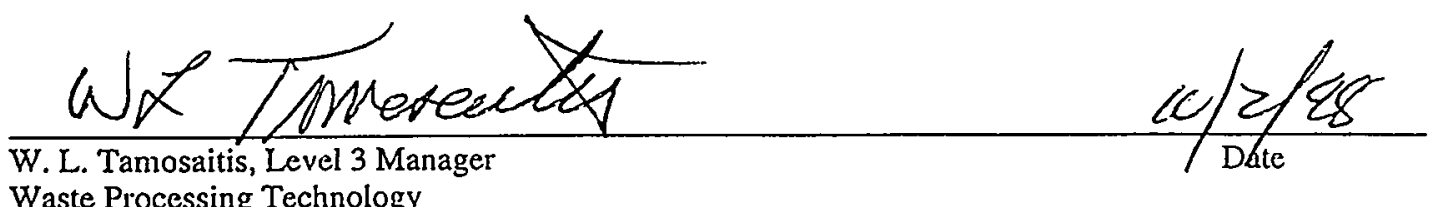

Waste Processing Technology

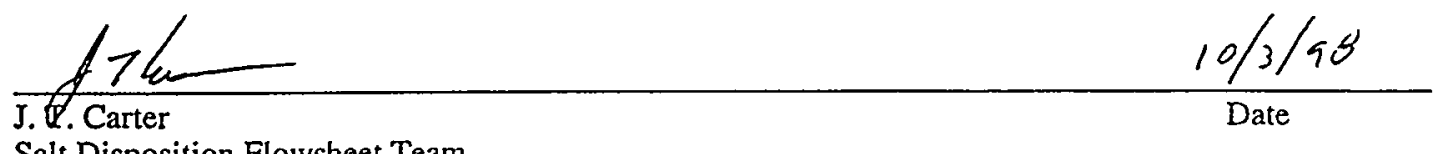

Salt Disposition Flowsheet Team

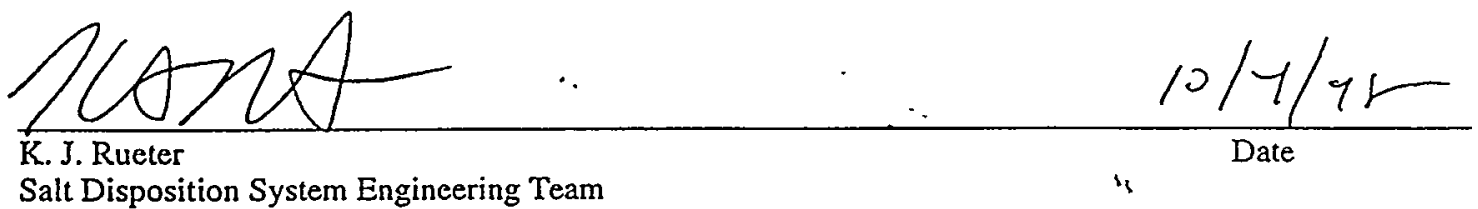


WSRC-TR-98-00338

Revision: 0

September 30, 1998

\title{
CERAMICRETE STABILIZATION OF CST RESIN: SALT WASTE ALTERNATIVE PHASE II FEASUBMITY STUDY (U)
}

\author{
Christine A. Langton, \\ Westinghouse Savannah River Company \\ Savannah River Technology Center, \\ Aiken, SC 29808
}

\section{SUMMARY}

The Ceramicrete ${ }^{\mathrm{TM}}$ waste form is a magnesium phosphate hydrate, which sets as the result of an acid-base reaction between $\mathrm{KH}_{2} \mathrm{PO}_{4}$ and $\mathrm{MgO}$ in the presence of water. Based on the results of this feasibility study, this low temperature ceramic waste form is acceptable for stabilization of cesium loaded crystalline silicotitanate (CST) resin. The performance objective of CST stabilization is to convert a friable powdered resin into a monolithic form to improve handling and storage and to reduce the waste mobility.

Advantages of this type of the CST-Ceramicrete ${ }^{\mathrm{TM}}$ waste form include: room temperature processing of a fluid slurry, limited off gas, flexible mix designs, rapid setting, no free liquids, temperature tolerant and durable up to at least $90^{\circ} \mathrm{C}$. The Ceramicrete $^{T M}$ waste form can be processed by in-container mixing or by batch mixing. Since a trace amount of free water will be associated with the wet resin in the CSTCeramicrete $^{\mathrm{TM}}$ waste form, radiolysis of the free water may cause pressurization of the containers.

Leaching tests were conducted to evaluate the CST-Ceramicrete ${ }^{\mathrm{TM}}$ waste form performance relative to high-level waste glass. Results were very encouraging given that only one waste loading ( $50 \mathrm{wt} . \%$ resin) was tested and that the leaching procedures were not fully optimized for a non-glass waste form.

In general, the cesium leachability per the PCT test of the CST-Ceramicrete ${ }^{\mathrm{TM}}$ waste was about $2 \mathrm{X}$ more than that of the ARM glass and about $200 \mathrm{X}$ more than the EA glass. For monolithic samples (MCC-1 test); the CST-Ceramicrete ${ }^{\mathrm{TM}}$ waste form leached $4 \mathrm{X}$ to $7 \mathrm{X}$ more cesium than the ARM glass. (The EA glass is not suited to monolithic leaching.) The CST-Ceramicrete ${ }^{\mathrm{TM}}$ leaching results appear to be independent of curing temperature over the range 24 to $90^{\circ} \mathrm{C}$. 
WSRC-TR-98-00338

Revision: 0

September 30, 1998

\section{BACKGROUND}

\section{SALT Disposition Alternative}

Removal of cesium from the high-level waste salt solution using crystalline silicotitanate resin (CST) is one of the alternatives identified in WSRC-RP-98-00166. Several options, such as vitrification and ceramic stabilization, were also identified for treating/managing the cesium loaded CST. ${ }^{1}$ In the case of a ceramic waste form, the assumption made in WSRC-RP-98-00166 was that it would be stored on-site until the cesium activity is negligible (about 300 years). The decay heat generated by the cesium would be managed and removed during the early years of storage. Another option (current option) for the CST-ceramic waste form is to dispose of it in the HLW Federal Repository.

The objective of treating the Cs-loaded CST by stabilization is to produce a more or less monolithic waste form to reduce the potential for dispersable and respirable fines. The particle size of the CST resin is in the range of 250 to $450 \mathrm{um}$. In addition, since the resin will be washed prior to removing it from the processing columns, it will require solidification or removal of any drainable liquid associated with the wet resin. This liquid will contain a small amount of soluble cesium. Stabilization in a ceramic waste form will reduce the mobility of this contaminant relative to no treatment.

The Test Plan for this feasibility study is presented elsewhere. ${ }^{2}$

\section{Ceramic Waste Form}

Ceramicrete ${ }^{\text {TM }}$ is the name of the hydrated magnesium phosphate waste form patented by Argonne National Laboratory. The binder in this waste form is produced by an acid-base reaction between magnesium oxide, $\mathrm{MgO}$, and monopotassium phosphate, $\mathrm{KH}_{2} \mathrm{PO}_{4}$ in the presence of water. The solid reaction product is $\mathrm{MgKPO}_{4} 6 \mathrm{H}_{2} \mathrm{O}$.

The mechanism for the magnesium phosphate stabilization is precipitation or adsorption of divalent and multivalent metals plus microencapsulation of precipitates and particulates. In the case of the Cs-loaded CST resin, the mechanism for stabilization is expected to be microencapsulation of the resin. The resin is the primary material for reducing the leachability of cesium.

\section{EXPERIMENTAL METHOD}

\section{Preparation of Cs-Loaded CST}

The CST used in these experiments was IONSIV IE-911, 30-60 mesh particles, Lot number 999096810002 , obtained from UOP, Inc., Des Plaines, IL. . The cesium-loaded CST (160 g) was prepared in four steps. In the first step, the dry CST was equilibrated with humid air. Next, the CST was washed in upward flowing water to remove fines. In the third step, the CST was shaken in 2 molar $\mathrm{NaOH}$ solution for 48 hours. Finally, the CST slurry in $\mathrm{NaOH}$ solution was placed in a vertical column and the excess $\mathrm{NaOH}$ solution drained to the top of the CST bed. The column of CST was washed with 400 
WSRC-TR-98-00338

Revision: 0

September 30, 1998

$\mathrm{mL}$ of salt solution (Table I) at a flow rate of $10 \mathrm{~mL} / \mathrm{min}$. After displacing the $\mathrm{NaOH}$ solution with salt solution, the CST:was shaken in salt solution (160 g CST/864 mL of salt solution) for four days to load the CST with cesium and potassium. At the end of four days, the cesium concentration in the salt solution was $88 \mathrm{mg} / \mathrm{L}$ and the potassium concentration was $810 \mathrm{mg} / \mathrm{L}$. The loaded resin was returned to the column and washed with 3 column volumes of $1 \mathrm{M} \mathrm{NaOH}$ and 3 column volumes of water to remove the salt solution. The $\mathrm{pH}$ of the final water from the column washing was greater than 13 .

\section{TABLE 1. Initial Composition of Salt Solution Used for Loading CST Particles.}

\begin{tabular}{ll} 
Component & Concentration (molar) \\
\hline $\mathrm{Nat}$ & 5.6 \\
$\mathrm{~K}+$ & 0.030 \\
$\mathrm{Cs}+$ & 0.02 \\
$\mathrm{NO} 3-$ & 2.2 \\
$\mathrm{NO} 2-$ & 0.51 \\
$\mathrm{OH}-$ & 1.91 \\
$\mathrm{AlO} 2-$ & 0.31 \\
$\mathrm{CO} 32-$ & 0.16 \\
$\mathrm{SO} 42-$ & 0.15 \\
$\mathrm{PO} 43-$ & 0.010 \\
$\mathrm{Cl}-$ & 0.025 \\
F- & 0.032 \\
$\mathrm{C} 2 \mathrm{O} 42-$ & 0.008 \\
SiO32- & 0.004 \\
MoO4- & 0.0002
\end{tabular}

The cesium and potassium loadings on the CST were calculated to be 1.4 and $0.19 \mathrm{wt} \%$, respectively. The preparation of the CST resin was carried out by D. D. Walker, WPT/SRTC specifically for these Ceramicrete ${ }^{T M}$ waste form feasibility experiments.

\section{Preparation of CST-Ceramicrete ${ }^{T M}$ Waste Forms}

The Ceramicrete ${ }^{\mathrm{TM}}$ reagent material was obtained from D. Singh, Argonne National Laboratory. The reagents used in this feasibility study were premixed by D. Singh. Consequently, only a single solid stabilization reagent was added to the CST resin. The Ceramicrete ${ }^{\mathrm{rM}}$ waste form is proportioned so that the amounts of $\mathrm{MgO}$ and $\mathrm{KH}_{2} \mathrm{PO}_{4}$ in the reagent plus the added $\mathrm{H}_{2} \mathrm{O}$ result in the stoichiometric amounts required to produce $\mathrm{MgKPO}_{4} \cdot \mathrm{H}_{2} \mathrm{O}$. A 50 weight percent CST loading was used in all of the batches. Since the amount of Cs-loaded CST was limited, only one waste loading was investigated. The batch sizes were relatively small and are listed below in Table 2 .

Table 2. Ingredients in the CST-Ceramicrete ${ }^{T M}$ Waste Forms. 
WSRC-TR-98-00338

Revision: 0

September 30, 1998

\begin{tabular}{|c|c|c|c|}
\hline Batch & $\begin{array}{c}\text { Ceramicrete } \\
\text { Reagent } \\
(\mathrm{g})\end{array}$ & $\begin{array}{c}\text { Cs-Loaded } . \cdot \\
\text { CST resin } \\
(\mathrm{g})\end{array}$ & $\begin{array}{c}\text { Deionized } \\
\text { Water } \\
(\mathrm{g})\end{array}$ \\
\hline 1 & 34.8 & $50^{*}$ & $15.2^{*}$ \\
\hline 2 & 34.8 & $50^{*}$ & $11.5^{*}$ \\
\hline 3. & 34.8 & $50^{*}$ & $11.5^{*}$ \\
\hline 4 & 53.24 & $76.5^{*}$ & $17.6^{*}$ \\
\hline
\end{tabular}

*The water content of the resin was determined to be $5.9 \mathrm{wt}$ \% by D. Singh. This value was used to calculate the amounts of water subtracted from the water required by the stoichiometric recipe for each batch.

The water content of the wet cesium-loaded CST resin was probably higher than that used in the formulation calculations. The mixtures were very thin and the amount of water was decreased to compensate for low moisture content measured. This occurred because the drying time for the sample was limited. The $\mathrm{pH}$ of the liquid decanted from the CST prior to mixing with the Ceramicrete ${ }^{T M}$ was 12.3.

The mixing procedure for the CST-Ceramicrete ${ }^{\mathrm{TM}}$ waste form was to combine the solid reagent and the CST and then add the water. The resulting mixtures were very fluid. All mixing was done with a spatula in a $250 \mathrm{ml}$ plastic beaker. The mixing time varied between 20 and 30 minutes. An increase in temperature and the onset of thickening were indications that sufficient mixing had occurred. Once thickening began, the time to setting (or paste formation) was very quick, and casting the samples into 10 and $20 \mathrm{ml}$ syringes was difficult. Heat was generated from the acid-base reactions. After filling the syringes were wrapped in thick paper towels for insulation to assure complete reaction. Set control can be achieved in this system in a variety of ways. The most common chemical set retarder for the phosphate systems is borate. No set modifiers were necessary in these small-scale experiments.

Samples were cured at ambient temperature $\left(23\right.$ to $\left.26^{\circ} \mathrm{C}\right)$ in sealed syringes for seven days. The samples were then divided and cured in sealed containers at $24.5,45,70$ and $90^{\circ} \mathrm{C} \pm 5^{\circ} \mathrm{C}$ for another seven days at $100 \%$ relative humidity.

\section{Testing}

The samples were demolded and inspected for cracks and integrity. The PCT and MCC-1 leach tests were requested by R. A. Jacobs, Alternatives Flowsheet Team, in order to compare the CST-Ceramicrete ${ }^{T M}$ waste to high-level wäste glass performance.

The PCT and MCC-1 tests are used to characterize high-level waste glass and ceramic waste forms. The ARM glass was used as a baseline for the MCC-1 test and the EA and ARM glasses were used for comparison of the PCT test results. (The compositions of the ARM and EA glasses are given in Attachment I.) Consequently, samples were prepared 
WSRC-TR-98-00338

Revision: 0

September 30, 1998

for the following tests to determine the relative leachability of cesium under various leaching conditions.

Test

TCLP Test

PCT Test ${ }^{4}$

dure

MCC-1 Test (Matrix B) ${ }^{3}$

EPA

ASTM C 1285-94

ASTM C1220-92

The PCT test was carried out according to the ASTM procedure except for the following modification. The crushed sample, shown in Figure 1A, was washed three times in ASTM leachate and three times in alcohol to remove fines per the procedure. However, the samples were not washed in alcohol in the ultra sonic cleaner because of a concern of size reducing the entire sample to a particle size which would not settle from the wash water. Figure 1B illustrates the large amount of suspended fines in this type of ceramic waste form. If the PCT test is to be run on additional Ceramicrete ${ }^{T M}$ samples, it is recommended that the Ceramicrete ${ }^{T M}$ samples be dried prior to grinding and care be taken not to over grind the samples.

The MCC-1 test was conducted per the ASTM procedure except that it was not possible to polish the samples to a smooth 600 grit finish. A CST-Ceramicrete ${ }^{T M}$ sample cut and polished for the MCC-1 test is shown in Figure 1C. The sample clearly consists of two solid phases. The gray material is the magnesium phosphate matrix and the white particles are the CST resin. The MCC-1 test was conducted according to a modified version of Matrix B of the ASTM procedure. This matrix evaluates waste form performance as a function of leaching time over a 28-day period. Only the 3 and 7 day periods were used for this feasibility evaluation. A brief description of the different leach test is presented in Table 3.

Table 3. Comparison of Leach Tests.

\begin{tabular}{|l|l|l|l|}
\hline & TCLP & PCT & MCC-1 \\
\hline Leachate & $\begin{array}{l}\text { Acetic/nitric acid } \\
\text { mixture }\end{array}$ & $\begin{array}{l}\text { ASTM-1 } \\
\text { Distilled water }\end{array}$ & $\begin{array}{l}\text { ASTM-1 } \\
\text { Distilled water }\end{array}$ \\
\hline Time & 18 hours & 7 days & $\begin{array}{l}3,7,14,28 \text { days } \\
\text { (matrix B) }\end{array}$ \\
\hline Temperature & Ambient & $90^{\circ} \mathrm{C}$ & $90^{\circ} \mathrm{C}$ \\
\hline Agitation & Rotated & static & static \\
\hline Particle Size & $<3 / 8$ inch & $100-200$ mesh & monolithic \\
\hline Leachate volume & $20 \times$ wt of sample & $10 \times$ wt of sample & $\begin{array}{l}\text { 10 xurface area } \\
\text { of sample }\end{array}$ \\
\hline
\end{tabular}

In addition, powder pattern $x$-ray diffraction was used to determine the phases in these waste forms as a function of curing temperature. Scanning electron microscopy and energy dispersive $x$-ray analyses were used to characterize the microstructure and to evaluate the possibility of microscopic interaction between the matrix and the CST. 
WSRC-TR-98-00338

Revision: 0

September 30, 1998

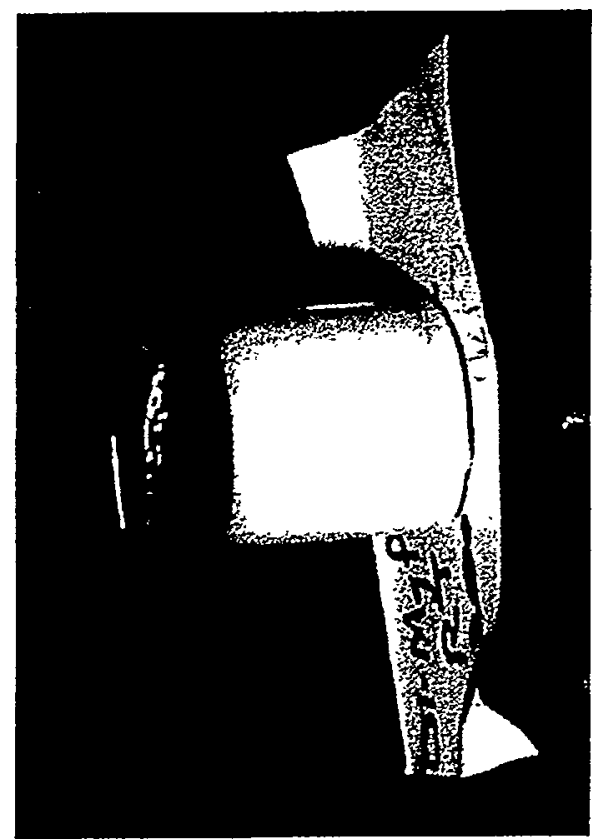

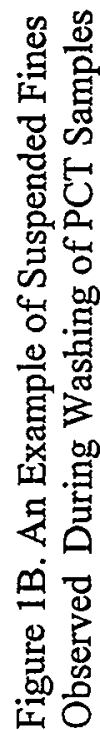

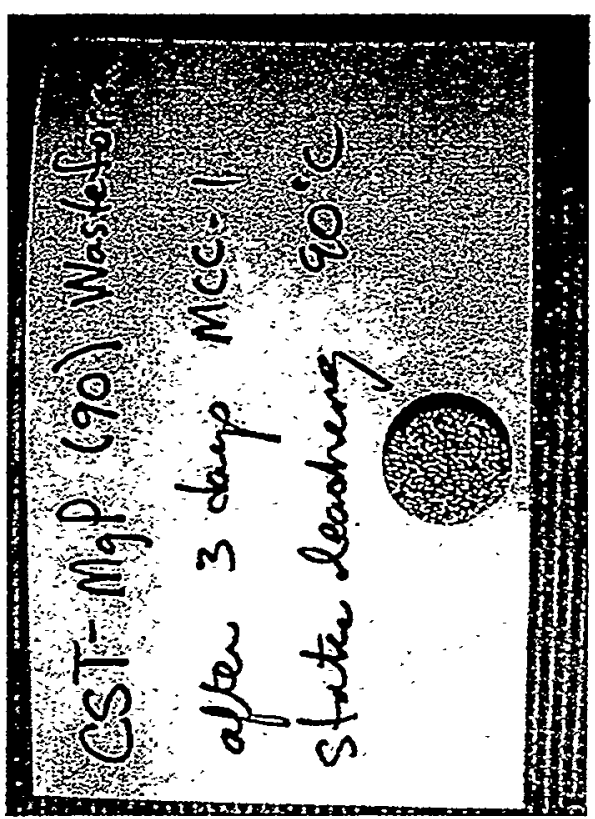

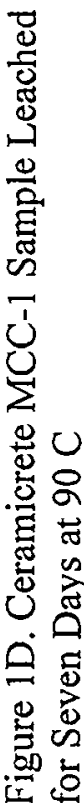

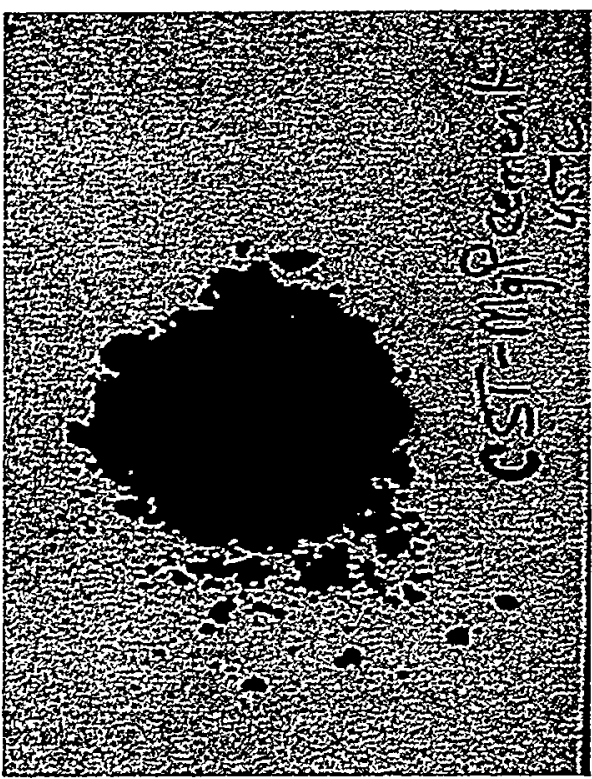

范

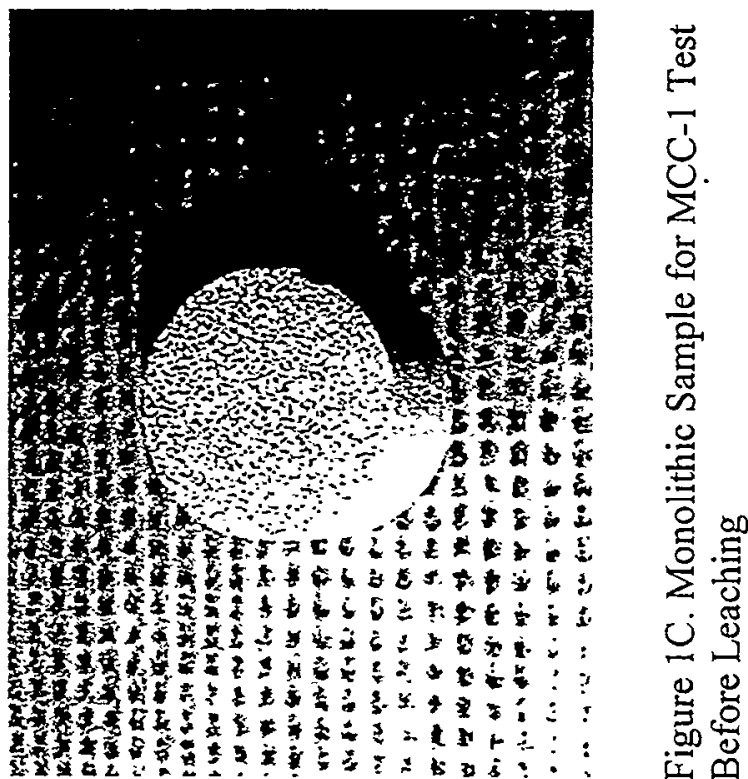


WSRC-TR-98-00338

Revision: 0

September 30, 1998

\section{RESULTS AND DISCUSSION}

\section{Sample Preparation}

All samples were very easy to mix at the 50 weight percent CST loading. The resulting slurries were very fluid. Continuous mixing was required to prevent settling of the CST resin. After 25 to 30 minutes of mixing, the slurry thickened to a paste and became too viscous to pour. In some cases the thickening occurred so quickly that it was difficult to transfer the material into the forms. The acid-base reaction responsible for this type of setting also generated heat during the rapid setting. (Temperature measurements were not made at the time the samples were prepared.)

\section{Matrix Phase Determination}

The matrix phase in the Ceramicrete ${ }^{\mathrm{TM}}$ waste forms cured at $24.5,45,70$, and $90^{\circ} \mathrm{C}$ is $\mathrm{MgKPO}_{4}\left(\mathrm{H}_{2} \mathrm{O}\right)_{6}$. In all cases a small amount of unreacted $\mathrm{MgO}$ and $\left(\mathrm{KPO}_{2}\right)_{6}\left(\mathrm{H}_{2} \mathrm{O}\right)_{8}$ were also detected in samples cured between 24 and $90^{\circ} \mathrm{C}$. The CST resin did not react with the magnesium phosphate binder over the temperature range studied. In addition, the crystalline structure of the CST resin shows no significant change as a function of curing temperature in the presence of the magnesium phosphate binder.

\section{Microstructure of the CST-Ceramicrete ${ }^{\mathrm{TM}}$ Waste Forms}

Scanning electron micrographs of the CST-Ceramicrete ${ }^{\mathrm{TM}}$ waste form are shown in Figure $2 \mathrm{a}-\mathrm{d}$. The round particles about 200 to $400 \mathrm{um}$ in diameter are the CST resin particles. As illustrated, in Figures $2 a-c$, they are relatively evenly distributed throughout the matrix and are microencapsulated by the matrix phases. Figure $2 d$ illustrates the microstructure of the magnesium phosphate hydrate in the matrix phase. The needles of $\mathrm{MgKPO}_{4} 6 \mathrm{H}_{2} \mathrm{O}$ are less than 10 to about 100 um long and are inter grown to form a matrix material. Very small needles of the matrix phase have also grown into the pores in the CST resin as shown in Figure $2 \mathrm{~b}$. This interlocking of the needles in the matrix phase accounts for the monolithic nature of the waste form. The small spheres observed in Figure $2 \mathrm{~d}$ are fly ash particles which were in the Ceramicrete ${ }^{\mathrm{TM}}$ premixed reagent material.

Total Cesium Analyses on the CST and CST-Ceramicrete ${ }^{T M}$ Waste Forms The cesium loaded CST resin was analyzed for total cesium. Prior to the analysis, the supernate in contact with the CST resin was decanted. The CST resin was not washed more than as described in the preparation procedure and it was not dried prior to the analysis. The cesium loading on the resin was determined to be $1.27 \mathrm{wt} \%$ based on a total digestion and ICP-MS analysis. This agrees very well with the loading of $1.4 \mathrm{wt} . \%$ calculated by D. D. Walker, WPT. The slightly lower value reported here is the result of the sample not being dried prior to the analysis. 

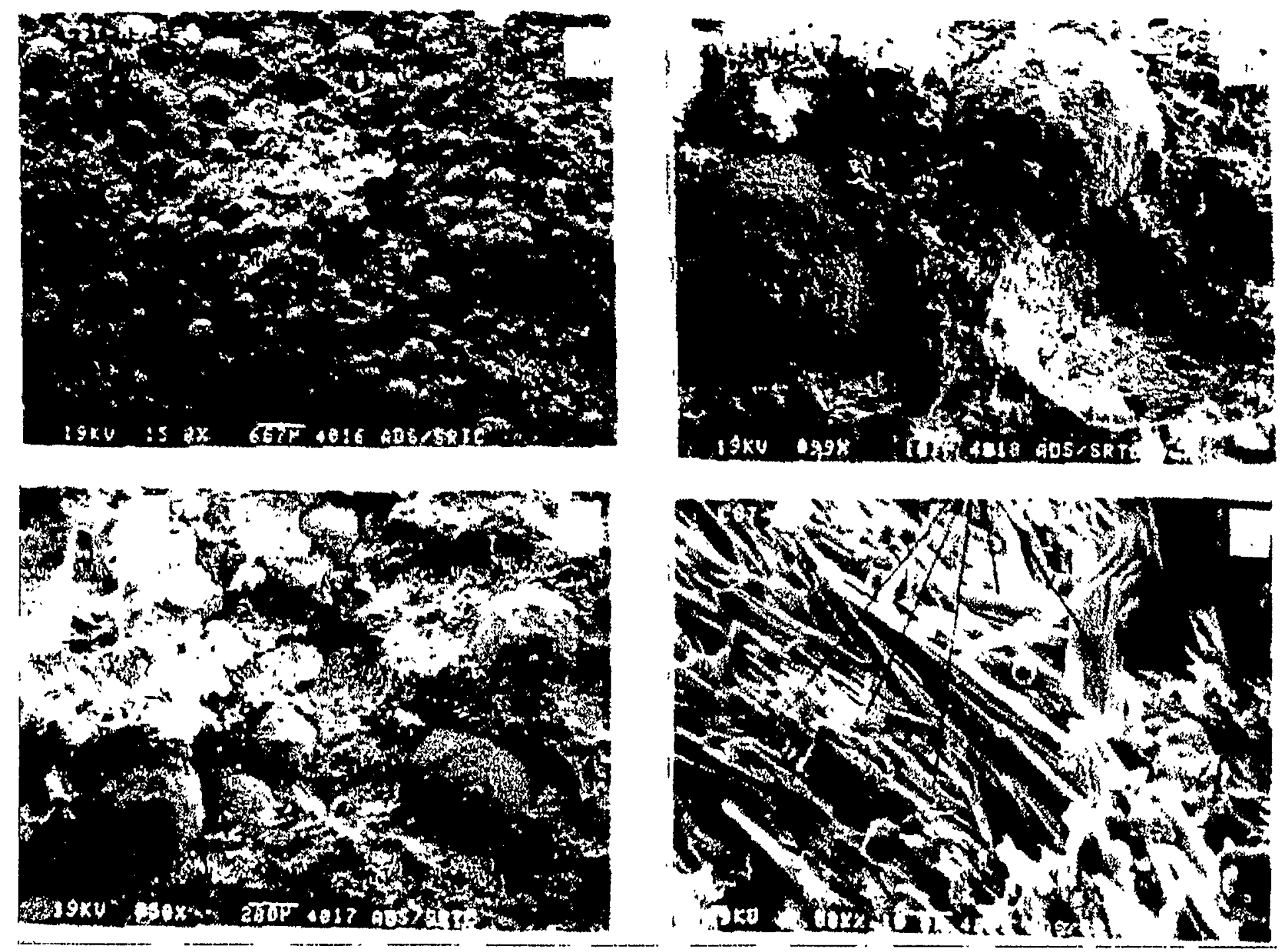

Figure 2 a-c. Photomicrographs illustrating microencapsulation of Cs-loaded CST in the ceramicrete matrix.

Figure 2 d. Microstructure of the ceramicrete matrix. The needle-shaped phase is $\mathrm{MgKPO}_{4} \bullet 6 \mathrm{H}_{2} \mathrm{O}$ 
The total cesium concentration in the supernate liquid decanted from the resin was measured to be $3290 \mathrm{ug} / \mathrm{L}$. The total cesium concentrations in the CST-Ceramicrete ${ }^{\mathrm{TM}}$ waste forms cured at $24.5,45,70$ and $90^{\circ} \mathrm{C}$ are shown in the Table 4 .

The total cesium concentrations measured for the CST-Ceramicrete ${ }^{\mathrm{TM}}$ waste forms are lower than expected for a $50 \mathrm{wt}$. \% waste loading. Since the CST contained $12.7 \mathrm{~g}$ of Cs per $\mathrm{kg}$ of CST, the waste forms should contain $6.35 \mathrm{~g}$ per $\mathrm{kg}$ of Ceramicrete ${ }^{\mathrm{TM}}$. The only explanation for this is that settling or phase separation of the resin from the aqueous slurry occurred at the time the samples were prepared. CST was under represented in the portion of the sample used in these experiments.

Table 4. Total Cesium Concentrations in the CST and CST-Ceramicrete ${ }^{\mathrm{TM}}$ Waste Forms.

\begin{tabular}{|l|l|c|c|c|}
\hline Sample ID & Sample Description & $\begin{array}{c}\text { Curing } \\
\text { Temperature } \\
\left({ }^{\circ} \mathrm{C}\right)\end{array}$ & $\begin{array}{c}\text { Cesium } \\
\text { Concentration } \\
(\mathrm{ug} / \mathrm{kg}, \mathrm{ppb})\end{array}$ & $\begin{array}{c}\text { Cesium } \\
\text { Concentration } \\
(\mathrm{g} / \mathrm{kg})\end{array}$ \\
\hline 98-SL01 & Cs loaded CST & $\mathrm{NA}$ & $12.7 \mathrm{E}+6$ & $\begin{array}{c}12.7 \\
(1.27 \mathrm{wt} \%)\end{array}$ \\
\hline 98-SL02 & $\begin{array}{l}\text { Filtered Supernate from } \\
\text { CST preparation }\end{array}$ & $\mathrm{NA}$ & $3.29 \mathrm{E}+3$ & \\
\hline 98-GLL-003 & $\begin{array}{l}\text { Ceramicrete w/50 wt \% } \\
\text { CST loading }\end{array}$ & 24.5 & $2.79 \mathrm{E}+6$ & 2.79 \\
\hline 98-GLL-004 & $\begin{array}{l}\text { Ceramicrete w/50 wt \% } \\
\text { CST loading }\end{array}$ & 45 & $2.39 \mathrm{E}+6$ & 2.39 \\
\hline 98-GLL-002 & $\begin{array}{l}\text { Ceramicrete w/50 wt \% } \\
\text { CST loading }\end{array}$ & 70 & $3.26 \mathrm{E}+6$ & 3.26 \\
\hline 98-GLL-001 & $\begin{array}{l}\text { Ceramicrete w/50 wt \% } \\
\text { CST loading }\end{array}$ & 90 & $3.67 \mathrm{E}+6$ & 3.67 \\
\hline
\end{tabular}

\section{TCLP Cesium Extraction Results for CST-Ceramicrete ${ }^{T M}$ Waste Forms}

The TCLP extraction test was conducted on the CST resin and on the CST-Ceramicrete ${ }^{\mathrm{TM}}$ waste forms cured at various temperatures. The TCLP extracts were analyzed for cesium. This test was conducted to obtain a rapid comparison of cesium leachability for samples cured at various conditions. There is no TCLP requirement for cesium.

Results are presented in Table 5. The amount of cesium in the TCLP extract from the pure cesium-loaded CST resin is about 3 times less than the amounts extracted from the CST-Ceramicrete ${ }^{T M}$ waste forms. However, the cesium concentration in the supernate liquid associated with the CST was measured at $3290 \mathrm{ug} / \mathrm{L}$. This supernate could be the source of the higher concentrations of cesium observed in the TCLP extracts of the waste forms since wet CST was used to prepare these waste forms. In addition, the leachability of cesium appears to increase slightly for curing temperatures between 24.5 and $90^{\circ} \mathrm{C}$. 
WSRC-TR-98-00338

Revision: 0

September 30, 1998

Table 5. TCLP Results for the CST and CST-Ceramicrete ${ }^{\mathrm{TM}}$ Waste Forms

\begin{tabular}{|c|c|c|c|}
\hline Sample ID & Curing Temperature & $\begin{array}{c}\text { Curing } \\
\text { Temperature } \\
\left({ }^{\circ} \mathrm{C}\right)\end{array}$ & $\begin{array}{c}\text { Cesium } \\
\text { Concentration } \\
\text { (ug/kg, ppb) }\end{array}$ \\
\hline 98-SL01 & Cs loaded CST & $\mathrm{NA}$ & 77 \\
\hline 98-SL02 & $\begin{array}{l}\text { Filtered Supernate } \\
\text { from final CST wash }\end{array}$ & $\mathrm{NA}$ & $3290(\mathrm{ug} / \mathrm{L})$ \\
\hline 98-GLL-003 & $\begin{array}{l}\text { Ceramicrete }^{T \mathrm{TM}} \mathrm{w} / 50 \mathrm{wt} \\
\% \text { CST loading }\end{array}$ & 24.5 & 194 \\
\hline 98-GLL-004 & $\begin{array}{l}\text { Ceramicrete }{ }^{\mathrm{TM}} \mathrm{w} / 50 \mathrm{wt} \\
\% \text { CST loading }\end{array}$ & 45 & 220 \\
\hline 98-GLL-002 & $\begin{array}{l}\text { Ceramicrete }{ }^{\mathrm{TM}} \mathrm{w} / 50 \mathrm{wt} \\
\% \mathrm{CST} \text { loading }\end{array}$ & 70 & 204 \\
\hline 98-GLL-001 & $\begin{array}{l}\text { Ceramicrete }{ }^{T M} \mathrm{w} / 50 \mathrm{wt} \\
\% \mathrm{CST} \text { loading }\end{array}$ & 90 & 268 \\
\hline
\end{tabular}

\section{PCT Leaching Results}

The Product Consistency Test (PCT) was conducted at the request of the Alternatives Flowsheet team. The objective was to compare the cesium leachability of the CSTCeramicrete ${ }^{T M}$ waste form to the glass waste forms which meet the high-level waste disposal criteria. Consequently, the cesium leachabilities of EA glass and ARM glass were also measured in this feasibility study. The PCT test results are listed in Table 6.

Considerably more cesium leached from the ARM glass than from EA glass, 1406 versus $11 \mathrm{ug} / \mathrm{L}$, respectively. On average, about 1.5 times as much cesium leached from the CST-Ceramicrete ${ }^{\mathrm{TM}}$ waste forms than the ARM glass.

The CST-Ceramicrete ${ }^{\mathrm{TM}}$ waste forms cured at 24.5 and $90^{\circ} \mathrm{C}$ leached slightly less cesium that did the samples cured at 45 and $70^{\circ} \mathrm{C}$. However, given that there were problems in the preparation of these samples with respect to 1) the CST settling out of the liquid Ceramicrete ${ }^{T M}$ matrix prior to setting, 2) removing the fines after crushing and sieving (Figure IB)and 3) the cesium contained in the aqueous phase of the wet CST used to stabilize the waste forms, these results are remarkably similar.

\section{MCC-1 Leaching}

The MCC-1 test was also conducted to compare the cesium leachability of the CST-

Ceramicrete $^{T M}$ waste form to that of the ARM glass which has been shown to be acceptable for high-level waste disposal. This test was carried out for 3 and 7 days to determine the effect of leaching time and also waste form curing temperature. Results are shown in Table 7. Samples leached for 7 days leached less cesium that samples cured for 3 days except for the 
WSRC-TR-98-00338

Revision: 0

September 30, 1998

CST-Ceramicrete ${ }^{\mathrm{TM}}$ waste form cured at $70 \mathrm{C}$, the Supernate-Ceramicrete ${ }^{\mathrm{TM}}$ waste form cured at $45 \mathrm{C}$, and the ARM glass. No trend was observed as a function of curing temperature. An example of the CST-Ceramicrete ${ }^{\mathrm{TM}}$ waste form after 3 days leaching at $90^{\circ} \mathrm{C}$ is shown in Figure 1D. The sample showed no sign of degradation after 7 days leaching.

Table 6. PCT Leaching Results for the CST-Ceramicrete ${ }^{\mathrm{TM}}$ Waste Forms.

\begin{tabular}{|c|c|c|c|}
\hline $\begin{array}{l}\text { Sample } \\
\text { Description }\end{array}$ & $\begin{array}{c}\text { Curing } \\
\text { Temperature } \\
\left({ }^{\circ} \mathrm{C}\right)\end{array}$ & $\begin{array}{c}\text { [Cs] in } \\
\text { Leachate } \\
\text { (ug/L) }\end{array}$ & $\begin{array}{c}\text { Average [Cs] } \\
\text { In Leachate } \\
\text { (ug/L) }\end{array}$ \\
\hline RT-1 & 24.5 & 1894 & \multirow{3}{*}{2303} \\
\hline RT-2 & 24.5 & 2403 & \\
\hline RT-3 & 24.5 & 2612 & \\
\hline $45-1$ & 45 & 1795 & \multirow{3}{*}{1663} \\
\hline $45-2$ & 45 & 1789 & \\
\hline $45-3$ & 45 & 1404 & \\
\hline $70-1$ & 70 & 1825 & \multirow{3}{*}{1906} \\
\hline $70-2$ & 70 & 1831 & \\
\hline $70-3$ & 70 & 2061 & \\
\hline $90-1$ & 90 & 2495 & \multirow{3}{*}{2422} \\
\hline $90-2$ & 90 & 2379 & \\
\hline $90-3$ & 90 & 2392 & \\
\hline B45-1 & 45 & 2576 & \multirow{3}{*}{2521} \\
\hline B45-2 & 45 & 2537 & \\
\hline B45-3 & 45 & 2451 & \\
\hline$\overline{\mathrm{EA}-1}$ & $\mathrm{NA}$ & 12.2 & \multirow{3}{*}{11} \\
\hline EA-2 & $\mathrm{NA}$ & 15.0 & \\
\hline EA-3 & $\mathrm{NA}$ & 15.8 & \\
\hline ARM-1 & $\overline{\mathrm{NA}}$ & 1140 & \multirow{3}{*}{1406} \\
\hline ARM-2 & NA & 1704 & \\
\hline ARM-3 & $\mathrm{NA}$ & 1375 & \\
\hline Blank-1 & $\overline{\mathrm{NA}}$ & 0.855 & \multirow[b]{2}{*}{0.7} \\
\hline Blank-2 & $\mathrm{NA}$ & $<0.6$ & \\
\hline
\end{tabular}


Table 7. MCC-1 Leaching Results for CST-Ceramicrete ${ }^{\mathrm{TM}}$ Waste Forms.

\begin{tabular}{|c|l|c|c|c|c|}
\hline $\begin{array}{c}\text { ADS } \\
\text { Sample } \\
\text { No. }\end{array}$ & Sample Description & $\begin{array}{c}\text { Leaching } \\
\text { Time } \\
\text { (days) }\end{array}$ & $\begin{array}{c}\text { Curing } \\
\text { Temperature } \\
{ }^{\circ} \mathrm{C}\end{array}$ & $\begin{array}{c}\text { Cs in } \\
\text { Leachate } \\
\text { (ug/L, ppb) }\end{array}$ & $\begin{array}{c}\text { Cs in } \\
\text { Leachate } \\
\text { corrected } \\
\text { for blank } \\
\text { (ug/L, ppb) }\end{array}$ \\
\hline 116747 & $\begin{array}{l}\text { CST-Ceramicrete } \\
50 \text { wt. \% loading }\end{array}$ & 3 & 24.5 & 3318 & 3188 \\
\hline 116748 & $\begin{array}{l}\text { CST-Ceramicrete } \\
50 \text { wt. \% loading }\end{array}$ & 3 & 45 & 3042 & 2912 \\
\hline 116749 & $\begin{array}{l}\text { CST-Ceramicrete } \\
50 \text { wt. \% loading }\end{array}$ & 3 & 70 & 1914 & 1784 \\
\hline 116750 & $\begin{array}{l}\text { CST-Ceramicrete } \\
50 \text { wt. \% loading }\end{array}$ & 3 & 90 & 3266 & 3136 \\
\hline 116751 & $\begin{array}{l}\text { Ceramicrete containing } \\
\text { decant water }\end{array}$ & 3 & 45 & 933 & 803 \\
\hline 116752 & ARM glass & 3 & NA & 611 & 481 \\
\hline 116753 & Blank & 3 & NA & 130 & NA \\
\hline 117145 & $\begin{array}{l}\text { CST-Ceramicrete } \\
50 \text { wt. \% loading }\end{array}$ & 7 & 24.5 & 3033 & 2944 \\
\hline 117150 & $\begin{array}{l}\text { CST-Ceramicrete } \\
50 \text { wt. \% loading }\end{array}$ & 7 & 45 & 2071 & 1982 \\
\hline 117154 & $\begin{array}{l}\text { CST-Ceramicrete } \\
50 \text { wt. \% loading }\end{array}$ & 7 & 70 & 2920 & 2831 \\
\hline 117157 & $\begin{array}{l}\text { CST-Ceramicrete } \\
50 \text { wt. \% loading }\end{array}$ & 7 & 90 & 2695 & 2606 \\
\hline 117161 & $\begin{array}{l}\text { Ceramicrete containing } \\
\text { decant water }\end{array}$ & 7 & 45 & 1107 & 1018 \\
\hline 117164 & ARM glass & 7 & NA & 891 & 802 \\
\hline 117169 & Blank & 7 & NA & 88.6 & NA \\
\hline
\end{tabular}


WSRC-TR-98-00338

Revision: 0

September 30, 1998

\section{CONCLUSIONS}

Ceramicrete ${ }^{\mathrm{TM}}$ is a magnesium phosphate low temperature ceramic waste form, which is chemically and physically compatible with cesium-loaded CST resin. Based on the limited testing conducted in this feasibility study, at 30 to $50 \mathrm{wt} \%$ loading, the waste form is temperature resistant, durable, monolithic, and has cesium leaching only slightly higher ( 4 to 7 times) than ARM glass for monolithic samples. This is very good considering that no optimization was conducted on the waste form or on the test method to adapt it to non-glass materials.

\section{RECOMMENDATIONS FOR ADDITIONAL TESTING}

Repeat leaching experiments and optimize the sample preparation and waste loading of the Ceramicrete ${ }^{T M}$ waste forms. Additional experiments are required to obtain statistical data for better comparisons.

Conduct radiolysis experiments to determine the rate of hydrogen generation from the CST-Ceramicrete ${ }^{\mathrm{TM}}$ waste forms as a function of Cs-137 loading.

Calculate hydrogen generation rates from the CST-Ceramicrete ${ }^{\mathrm{TM}}$ waste forms to determine the amount of ventilation required in the storage buildings to purge hydrogen generated by radiolysis. (Storage containers will require venting to prevent build up of hydrogen.)

Conduct experiments to optimize the processing properties of the CST-Ceramicrete ${ }^{\mathrm{TM}}$ waste form.

Evaluate the leaching of the CST and CST-Ceramicrete ${ }^{\mathrm{TM}}$ waste form prepared from actual waste or simulated waste containing the minor and trace constituents in the highcesium salt solution. For example, radionuclide and RCRA metal adsorption and subsequent leaching from the resin and ceramic waste form should be evaluated. 
WSRC-TR-98-00338

Revision: 0

September 30, 1998

\section{REFERENCES}

1. P. L. Rutland, et. al., Bases, Assumptions and Results of the Flowsheet Calculations for the Initial Eighteen Salt Disposition Alternatives, WSRC-RP-98-00166, 6-25-98.

2. C. A. Langton, "Test Plan for CST Resin in a $\mathrm{MgPO}_{4}$ Binder," SRT-WED-98-0115, 8-31-98.

3. ASTM C-1220-92, Standard Test Method for Static Leaching of Monolithic Waste Forms for Disposal of Radioactive Waste.

4. ASTM C 1285-94, Standard Test Method for Determining Chemical Durability of Nuclear Waste Glasses: The Product Consistency Test (PCT).

5. G. B. Mellinger and J. L. Daniel, "Approved Reference and Testing Material for Use in Nuclear Waste Management Research and Development Programs," PNL-4955-1, prepared for the USDOE under contract DE-AC06-76RLO 1830.

6. C. M. Jantzen, N. E. Bibler, D. C. Beam, C. L. Crawford, and M. A. Pickett, "Characterization of the Defense Waste Processing Facility (DWPF) Environmental Assessment (EA) Glass Standard Reference Material" (U), WSRC-TR-92-346, June 1, 1993.

\section{QUALITY ASSURANCE}

Results are recorded in WSRC-NB-98-00204. Testing was conducted in accordance with SRTC procedures.

\section{ACKTNOWLEGEMENTS}

D. Singh, Argonne National Laboratory, prepared the CST-Ceramicrete ${ }^{\text {TM }}$ waste forms and furnished the Ceramicrete ${ }^{T M}$ reagents.

D. D. Walker, SRTC, prepared the cesium loaded CST resin.

B. T. Butcher and L. Tovo, SRTC, expedited analytical results.

T. O. Burckhalter, P. A. Toole, and I. A. Reamer conducted the PCT and MCC-1 leaching tests. 
WSRC-TR-98-00338

Revision: 0

September 30, 1998

\section{ATTACHMENT I}

\section{COMPOSITIONS OF THE EA AND ARM GLASSES}




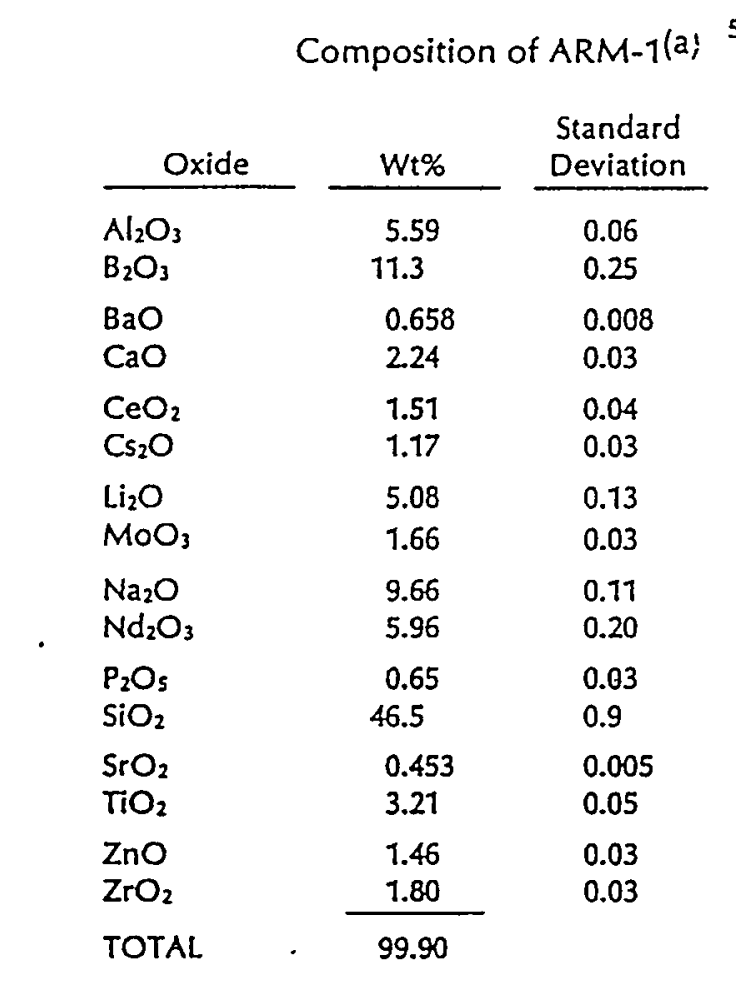

(a) Based on analysis of ten random samples, each sample analyzed twice. 
Savannah River Technology Center (SRTC) Chemical Analysis of the Environmental Assessment (EA) Glass 6

GLASS ID $=1-$ MISC-A

\begin{tabular}{|c|c|c|c|c|c|c|c|}
\hline & $\begin{array}{l}\text { ANALYTIC } \\
\text { TECHNIQUE }\end{array}$ & $\begin{array}{r}\text { ELEMEN } \\
\text { WT\% }\end{array}$ & $\begin{array}{l}\text { T GRAV } \\
\text { FACTOR }\end{array}$ & $\begin{array}{l}\text { OXIDE } \\
\text { WT\% }\end{array}$ & $\begin{array}{c}\text { BIAS } \\
\text { CORRECT } \\
\text { FACTOR }\end{array}$ & $\begin{array}{c}\text { BIAS } \\
\text { CORRECT } \\
\text { OXIDE WT } \%\end{array}$ & $\begin{array}{c}\text { NORM } \\
\text { OXIDE } \\
\text { WT } \%\end{array}$ \\
\hline $\mathrm{A} 12 \mathrm{O} 3$ & $\mathrm{Na} 2 \mathrm{O} 2 \mathrm{DISS} / \mathrm{CP}$ & 1.779 & 1.8895 & 3.3614 & 1.05 & $3: 5420$ & 3.3976 \\
\hline $\mathrm{CaO}$ & MW DISS/ICP & 0.881 & 1.3992 & 1.2327 & 1.00 & 1.2327 & 1.2460 \\
\hline $\mathrm{Fe} 203$ & MW DISS $/ C P$ & 6.437 & 1.429 .7 & 7.4277 & 1.00 & 7.4277 & 7.5077 \\
\hline $\mathrm{FeO}$ & REDOX & N/A & 1.2865 & 1.5974 & 1.00 & 1.5974 & 1.6146 \\
\hline $\mathrm{MgO}$ & MW DISS/ICP & 1.073 & 1.6583 & 1.7794 & 1.00 & 1.7794 & 1.7985 \\
\hline $\mathrm{MnO}$ & MW DISS/ICP & 1.051 & 1.2912 & 1.3571 & 1.00 & 1.3571 & 1.3717 \\
\hline $\mathrm{Na} 2 \mathrm{O}$ & MW DISS/ICP & 12.017 & 1.3480 & 16.1989 & 1.04 & 16.8993 & 16.3734 \\
\hline $\mathrm{Li} 2 \mathrm{O}$ & MW DISS/ICP & 1.947 & 2.1525 & 4.1909 & 1.00 & 4.1909 & 4.2360 \\
\hline $\mathrm{NiO}$ & MW DISS/ICP & 0.421 & 1.2726 & 0.5358 & 1.00 & 0.5358 & 0.5415 \\
\hline $\mathrm{SiO} 2$ & $\mathrm{Na2O} 2 \mathrm{DISS} / \mathrm{ICP}$ & P 22.569 & 2.1393 & 48.2819 & 1.02 & 49.3419 & 48.8018 \\
\hline $\mathrm{Cr} 2 \mathrm{O} 3$ & MW DISS/ICP & 0.000 & 1.4616 & 0.0000 & 1.00 & 0.0000 & 0.0000 \\
\hline $\mathrm{B} 203$ & $\mathrm{Na2O} 2 \mathrm{DISS} / \mathrm{ICP}$ & 3.516 & 3.2201 & 11.3219 & 1.00 & 11.3219 & 11.4438 \\
\hline UO2 & & & 1.1344 & 0.0000 & & 0.0000 & 0.0000 \\
\hline $\mathrm{ThO}_{2}$ & & & 1.1379 & 0.0000 & & 0.0000 & 0.0000 \\
\hline $\mathrm{SrO}$ & MW DISS/ICP & 0.000 & 1.1826 & 0.0000 & & 0.0000 & 0.0000 \\
\hline $\mathrm{ZrO2}$ & MW DISS/ICP & 0.327 & 1.3508 & 0.4417 & 1.00 & 0.4417 & 0.4465 \\
\hline $\mathrm{TiO} 2$ & MW DISS/ICP & 0.386 & 1.6680 & 0.6438 & 1.00 & 0.6438 & 0.6508 \\
\hline $\mathrm{K} 2 \mathrm{O}$ & MW DISS/AA & 0.034 & 1.2046 & 0.0408 & 1.00 & 0.0408 & 0.0413 \\
\hline $\mathrm{Cs} 2 \mathrm{O}$ & MW DISS/AA & 0.004 & 1.0602 & 0.0043 & 1.00 & 0.0043 & 0.0044 \\
\hline $\mathrm{Sb} 2 \mathrm{O} 3$ & & & 1.1970 & 0.0000 & & 0.0000 & 0.0000 \\
\hline P2O5 & MW DISS/ICP & 0.000 & 2.2910 & 0.0000 & 1.00 & 0.0000 & 0.0000 \\
\hline $\mathrm{Nd} 203$ & & & 1.1660 & 0.0000 & & 0.0000 & 0.0000 \\
\hline La2O3 & MW DISS/ICP & 0.228 & .1 .1728 & 0.2674 & 1.00 & 0.2674 & 0.2703 \\
\hline $\mathrm{Y} 2 \mathrm{O} 3$ & & & 1.2699 & 0.0000 & & 0.0000 & 0.0000 \\
\hline $\mathrm{BaO}$. & MW DISS/ICP & 0.000 & 1.1165 & 0.0000 & 1.00 & 0.0000 & 0.0000 \\
\hline $\mathrm{PbO}$ & MW DISS/ICP & 0.000 & 1.0772 & 0.0000 & & 0.0000 & 0.0000 \\
\hline $\mathrm{CeO}_{2}$ & & & 1.2284 & 0.0000 & & 0.0000 & 0.0000 \\
\hline $\mathrm{MoO} 3$ & MW DISS/ICP & 0.000 & 1.5003 & 0.0000 & 1.00 & 0.0000 & 0.0000 \\
\hline $\mathrm{ZnO}$ & MW DISS/ICP & 0.202 & 1.2447 & 0.2514 & 1.00 & 0.2514 & 0.2541 \\
\hline $\mathrm{CuO}$ & MW DISS $/ \mathrm{ICP}$ & 0.000 & 1.2518 & 0.0000 & 1.00 & 0.0000 & 0.0000 \\
\hline $\mathrm{Fe} 2+\sqrt{\mathrm{Fe}} 3+$ & & 0.239 & & & & & \\
\hline SUMS & & 52.872 & & 98.9346 & & 100.8756 & 100.0000 \\
\hline
\end{tabular}


WSRC-TR-98-00338

Revision: 0

September 30, 1998

\section{WESTINGHOUSE SAVANNAH RIVER COMPANY SAVANNAH RIVER TECHNOLOGY CENTER}

March 30, 1998

\section{Distribution:}

G. Abell, 704-3N

J. L. Barnes, 704-3N

S. B. Beck, 704-3N

B. T. Butcher, 773-43A

J. D. Carlson, 703-H

R. A. Dimenna, 773-42A

J. T. Carter, 703-25S

N. R. Davis, 703-H

H. H. Elder, 704-S

S. D. Fink, 773-A

J. R. Fowler, 704-3N

M. W. Geetings, 773-24A

T. Hang, 773-42A

P. Hudson, 704-3N

R. A. Jacobs, 704-3N

M. D. Johnson, 703-H

M. T. Keefer, 241-153H

P. S. Kirkland, 703-46A

G. Kosiancic, 704-3N

B. L. Lewis, 703-H

T. J. Lex, 703-H

J. W. McCollough, 703-H

M. S. Miller, 704-56H

T. M. Monahon, 703-H

J. P. Morin, 703-H

E. Murphy, 704-3N

L. M. Nelson, 773-43A

L. Papouchado, 773-A

P. K. Paul, 773-43A

R. A. Peterson, 773-A

S. F. Piccolo, 704-3N

K. J. Rueter, 706-S

P. L. Rutland, 704-196N

W. E. Stevens, 773-A
P. C. Suggs, 704-3N

W. L. Tamosaitis, 773-A

D. D. Walker, 773A

J. Watson, 704-3N

G. T. Wright, 773-A 